\title{
Synchronous skin squamous cell carcinoma and papillary thyroid carcinoma after renal transplantation: a case report
}

\author{
Omar Hamdy ${ }^{1}$, Sara Raafat ${ }^{2}$, Amr Abouzid ${ }^{1}$, Mahmoud M. Saleh ${ }^{1}$, Abdelhady M. Shebl ${ }^{2}$ \\ ${ }^{1}$ Surgical Oncology Unit, Oncology Center Mansoura University (OCMU) \\ ${ }^{2}$ Pathology Department, Faculty of Medicine, Mansoura University, Mansoura, Egypt
}

Dr. Omar Hamdy, Surgical Oncology Unit, Oncology Center

Phone: +201003526752

Mansoura University

E-mail: omarhamdy87@gmail.com

Citation: Hamdy O, Raafat S, Abouzid A et al. Synchronous skin squamous cell carcinoma and papillary thyroid carcinoma after renal transplantation: a case report. Cell Ther Transplant 2018; 7(4): 61-65

\section{Summary}

Secondary malignancies following renal transplantation are not an uncommon event. In this report we considered one of the causes of posttransplant mortality. We report a renal transplant case and immune suppression treatment followed 11 years later by synchronous skin squamous cell carcinoma and papillary thyroid carcinoma that was diagnosed, presented and managed at the Oncology Center at Mansoura University.

\section{Keywords}

Kidney transplantation, immunosuppressive drugs, synchronous malignancy.

\section{Introduction}

Renal transplantation is considered the best treatment modality for end-stage renal disease (ESRD), offering better survival than chronic hemodialysis. Yet, posttransplant malignancy is considered the second cause of death in renal transplant patients after cardiovascular diseases. Acquired immune deficiency caused by immunosuppressive drugs is supposed of being the cause of such high incidence. The most common malignancy in those patients is non-melanocytic skin cancer, while thyroid cancer is not very common and does not show a higher incidence than in general population [1-4].

\section{Case presentation}

The patient was a fifty-three year-old male, diabetic and hypertensive, married with two offsprings. He had a history of renal transplantation in April, 2004 from a living donor after suffering from end-stage renal disease (ESRD) secondary to hypertension. He was kept on immunosuppressant therapy, received cyclosporine (100 mg daily dose) for 11 years (2004-
2015), followed by sirolimus ( $1 \mathrm{mg}$ daily) for 3 years (2015 till now). He has been receiving daily doses of prednisone $(10 \mathrm{mg}$ ) and azathioprine (100 mg) from 2004 till now.

The patient had history of prior excision of right pre-auricular lesion in 2015, with histologically proven keratoacanthoma, followed after 6 months by wide local excision of a recurrent tumor at the same site with postoperative pathology revealing grade I squamous cell carcinoma (SCC, a primary malignancy), with free all safety margins from tumor tissue.

He was presented to our center in February 2017 complaining from right pre-auricular ulcer. Physical examination revealed good general condition with right pre-auricular ulcer, with raised everted edges, necrotic base and purulent discharge. Sonography of the neck region revealed enlarged distorted intraparotid lymph nodes, as well as an incidentally discovered left solitary thyroid nodule $1.5 \times 1.1 \mathrm{~cm}$ in size, the nodule was solid, iso-echoic with calcification foci, and with poorly defined outline, thus being classified as TIRADS 5 nodule. Computed tomography (CT) examination revealed a soft tissue swelling invading the skin and involving superficial lobe of the right parotid gland measuring $3 \times 2 \times 1 \mathrm{~cm}$. 
CT showed also two suspicious left cervical lymph nodes (LNs), the largest was 10x9x8 mm.

The patient underwent wide local excision of the tumor en bloc with superficial lobe of the right parotid gland, ipsilateral modified radical block neck dissection, as well as left hemithyroidectomy from which frozen sections were examined, showing no evidence for malignancy. Paraffin sections prepared from the surgical specimens revealed malignant tumor proliferation formed of malignant squamoid epithelial cell foci with frequent central keratin pearls separated by desmoplastic inflammatory stroma. The cells showed moderate pleomorphism, abundant eosinophilic cytoplasm, vesicular nuclei and prominent nucleoli. The tumor was seen to infiltrate adjacent parotid gland, and one of three intraparotid lymph nodes, with all twenty-seven lateral LNs being unaffected, leading to the diagnosis of pre-auricular grade I SCC infiltrating parotid gland, with tumor-negative lateral lymph nodes. (Fig. 1). Histological sections prepared from left thyroid lobe revealed multiple nodules showing malignant tumoral proliferation consisting of papillary structures lined by cuboidal epithelial cells showing nuclear overlapping, washing out and grooving with coffee bean appearance, thus leading to the final diagnosis of papillary thyroid carcinoma (Second malignancy, Fig. 2). Two weeks later, the patient underwent completion thyroidectomy and contralateral selective block neck dissection (levels II-V) which revealed a hyperplastic thyroid nodule and a single positive lateral lymph node infiltrated by papillary thyroid carcinoma.
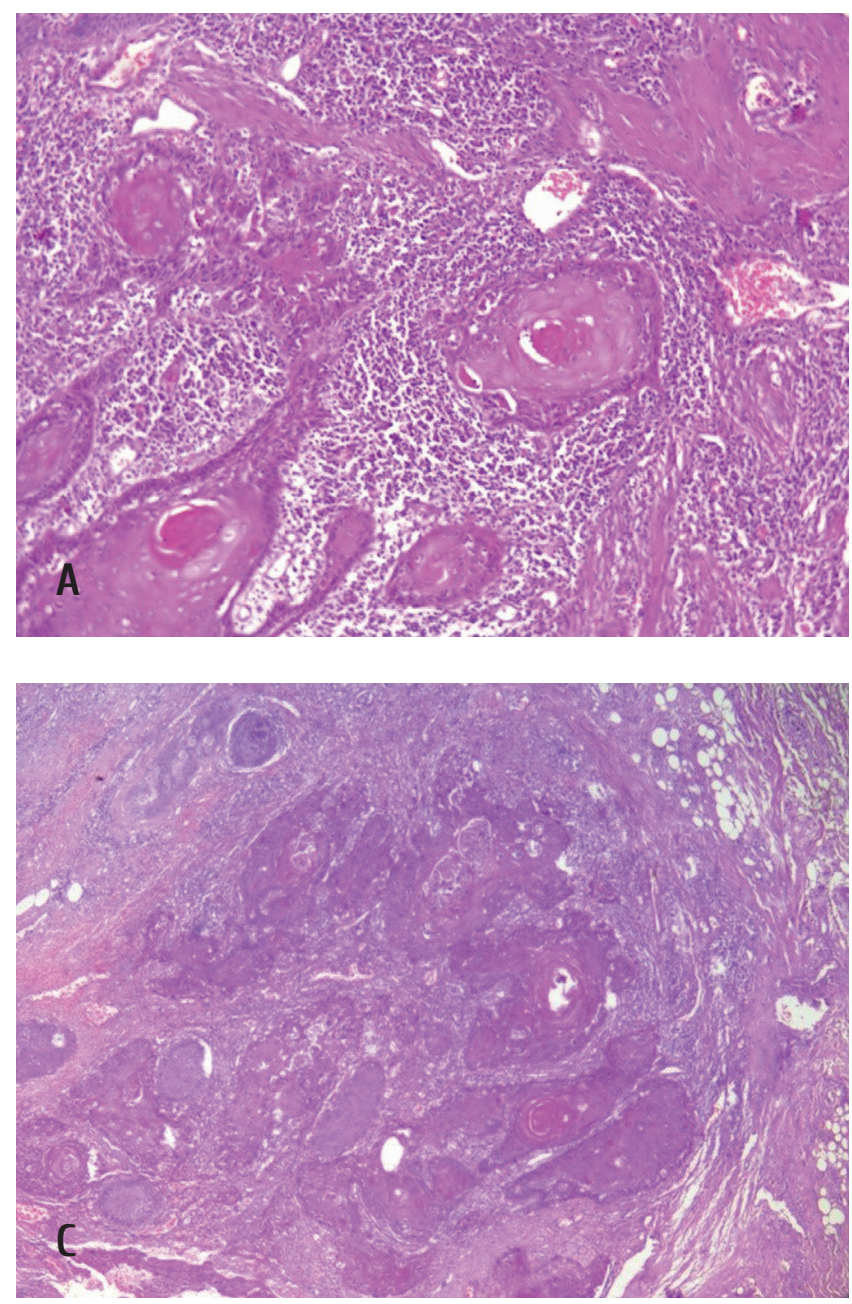

He was referred to Clinical Oncology Department for further management. In view of renal transplantation history, only one positive $\mathrm{LN}$ and that the patient was obsessive about nephrotoxic drugs, radioactive iodine was omitted, and the decision was to receive suppressive dose of L-thyroxine and radiotherapy on the SCC tumor bed.

Eight months later, the patient was presented with right thumb lesion. Histopatholigical examination of the biopsy showed pseudoepitheliomatous hyperplasia. Yet, wide local excision of the lesion with microscopic examination of the specimen described malignant tumoral proliferation formed of sheets and nests of malignant squamous epithelium showing moderate atypia and pleomorphism with focal central keratin pearls and dyskeratosis, thus leading to the diagnosis of grade II squamous cell carcinoma with free all safety margins from tumor tissue (Third malignancy, Fig. 3). Nine months later, he suffered from local recurrence in his right thumb for which he underwent thumb amputation with free surgical margin.

\section{Discussion}

Renal transplantation is considered the best treatment modality for patients with end-stage renal disease (ESRD) who are candidates for transplantation, with routine use of immunosuppressive therapy to prevent graft rejection. This makes transplantation not only a life-saving procedure, but also a life-changing one. The use of immunosuppressants led

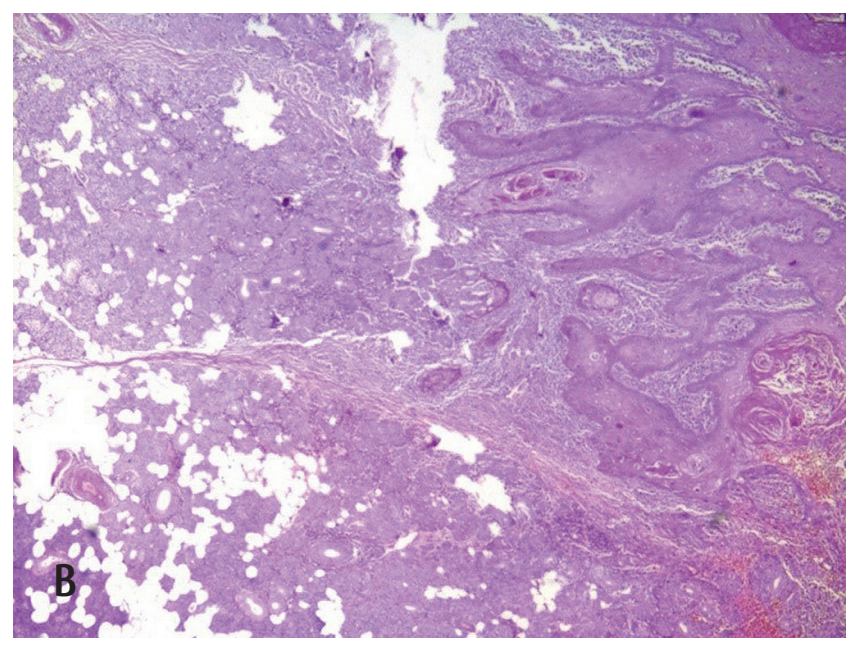

\section{Figure 1. Microscopic picture of the preauricular ulcer}

(a) Pre-auricular mass: Grade I squamous cell carcinoma. Nests of malignant squamoid epithelial cells with central keratin pearls and desmoplastic inflammatory stroma. H \& E x100 (b): Pre-auricular mass: Grade I squamous cell carcinoma. The tumor infiltrates the adjacent parotid gland. H \& E x40 (c): Pre-auricular mass: Grade I squamous cell carcinoma. The tumor infiltrates intratumoral lymph node. H \& E x40 

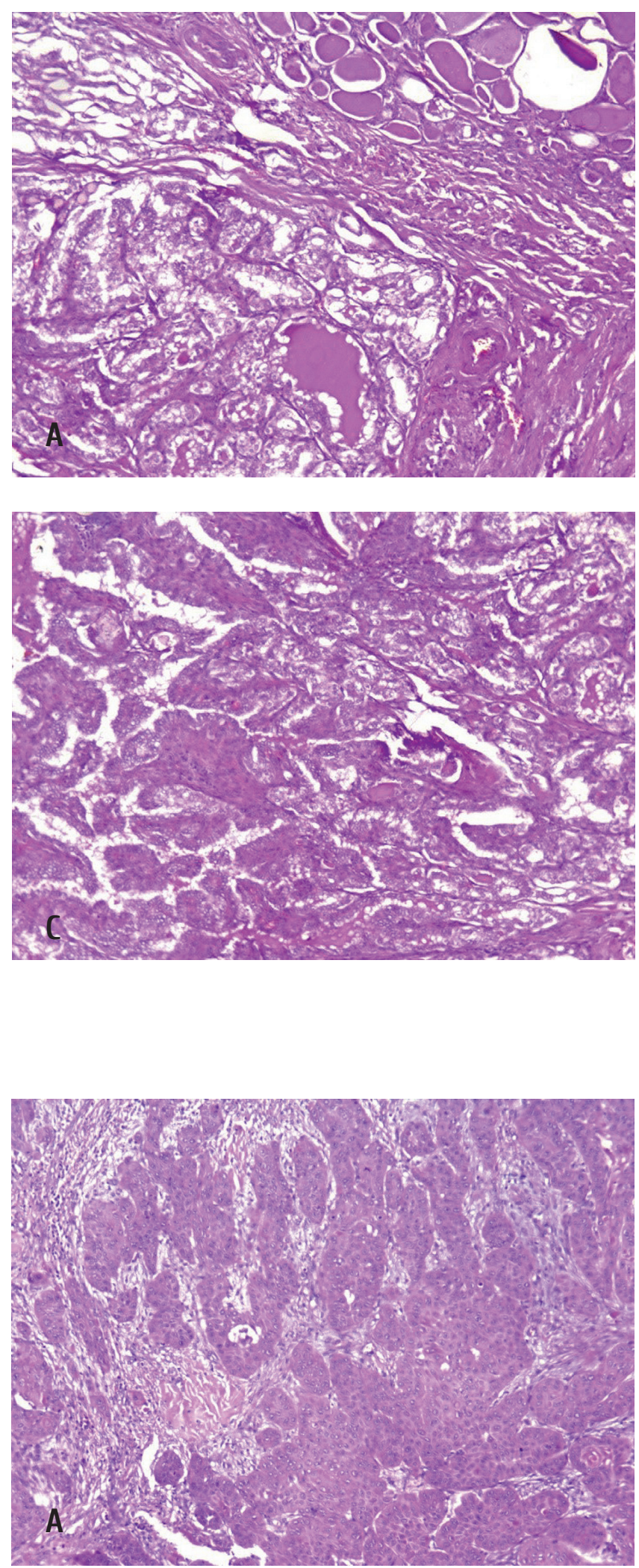

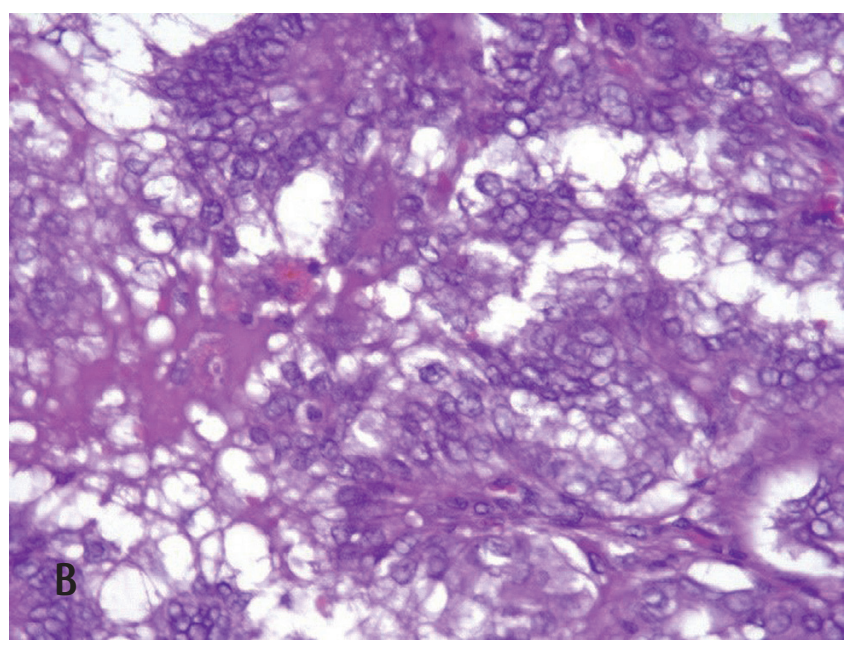

Figure 2. Microscopic picture of malignant thyroid lobe $\&$ cervical lymph node

(a) Left thyroid lobe: Papillary thyroid carcinoma. Infiltration of thyroid tissue by malignant tumoral proliferation formed of papillary structures lined by cuboidal epithelial cells with fibrovascular core. H \& E x100

(b) Left thyroid lobe: Papillary thyroid carcinoma. Papillary structures lined by cuboidal epithelial cells showing nuclear overlapping, washing out and grooving, with detected mitotic figures. $\mathrm{H} \& \mathrm{E}$ x400

(c) Lateral block neck dissection: Infiltration of one lymph node by papillary thyroid carcinoma. H \& E x100

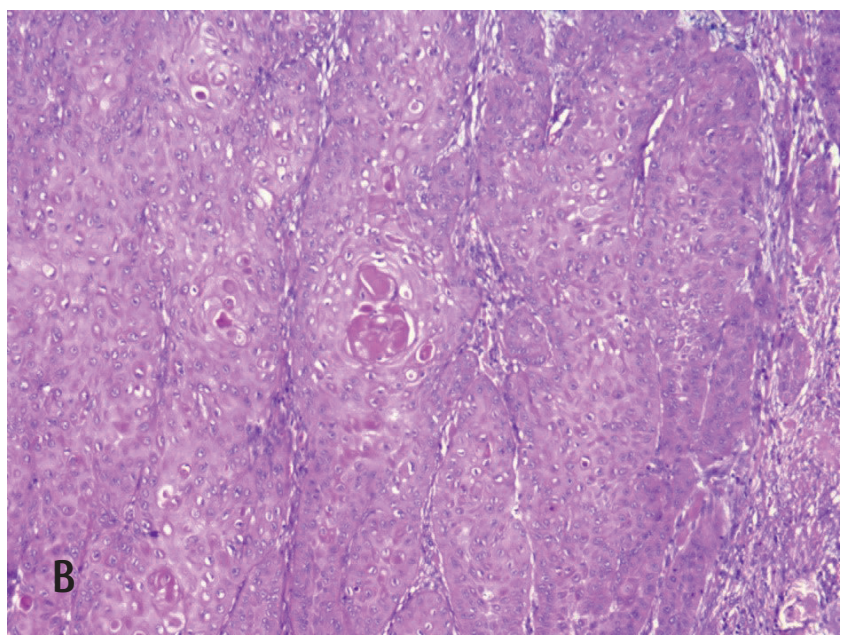

Figure 3. Microscopic picture of the thumb lesion

(a) Thumb lesion: Grade II squamous cell carcinoma. Sheets and nests of malignant squamoid epithelial cells with desmoplastic stroma. H \& E x100

(b) Thumb lesion: Grade II squamous cell carcinoma. Sheets and nests of malignant squamoid epithelial cells with moderate atypia and pleomorphism, central keratin pearls and dyskeratosis. $\mathrm{H} \& \mathrm{E}$ x100 
to increasing the risk for developing malignancy by about three- to four-fold compared to general population, with a reported incidence of $4-18 \%$. The transplanted patients are considered having higher risk for both incidence and mortality from cancer, being the second leading cause of death after cardiovascular diseases in this cohort. This is usually explained by lacking immunity surveillance allowing potentially neoplastic cells to proliferate due to opportunistic oncogenic viral infections or somatic mutations, DNA damage, increased age of transplanted population, more biologically aggressive tumors, as well as using less aggressive cancer treatment modalities, concerns for suppressed immunity and higher risk of graft rejection. Eventually, some of the immunosuppressive drugs are reported to have pro-carcinogenic properties. The most common malignancies among renal transplant patients are a non-melanocytic skin cancer followed by Kaposi sarcoma. Most of them are de novo malignancies rather than those recurrent of pre-transplant malignancy, or donor-derived tumors. The incidence of cancer is increased by the duration of immunosuppressive therapy and use of steroids [5-14]. Despite the developing malignancy does not affect graft survival, the reduction of malignancy risk among transplant patients is very important since they experience worse outcomes with increased cancer-related mortality. This may be achieved by using immunosuppressive drugs with antitumor effects or adopting low-level immunosuppression as well as regular cancer screening of the transplanted patients $[1,9,15]$. Specific cancer prevention, screening and treatment programs for people with solid organ transplantation are highly recommended $[4,13]$.

Once diagnosis of posttransplant malignancy is established, the adequate oncological management of the disease, as well as modulation of immunosuppressants should be performed, including dose reduction, withdrawal, or drug substitution, e.g., based on mammalian target of rapamycin (mTOR) inhibition. Their application is shown to be associated even with regression in non-metastatic malignancies $[16,17]$.

Non-melanocytic skin cancer (NMSC) is the most common malignancy in solid organ transplant patients and, especially, in renal transplant patients, with a 65-250-fold increased incidence risk. Squamous cell carcinoma is the most common NMSC type, followed by basal cell carcinoma with an incidence ratio 4:1, thus being different from general population where basal cell carcinoma is more common. Besides being more aggressive, it tends to be presented in multiple sites after the initial lesion. The risk for developing SCC is higher in light-colored skin people and those with long-term immunosuppression with tendency for multiplicity in the sun-exposed areas and higher risk for recurrence [11].

Thyroid cancer after renal transplantation shows non-significant higher incidence which may be explained by the use of immunosuppressive drugs, as well as routine diagnostics by performance of neck ultrasonography, due to associated hyperparathyroidism in ESRD patients. However, its incidence is increased in ESRD patients who did not undergo transplantation as well. Thyroid cancer in renal transplant patients shows the same prognosis and rate of recurrence as for general population, despite showing different gender distribution. These patients are advised to be treated with the same modalities as other thyroid cancer patients $[2,10]$.

\section{Conclusion}

Incidence of posttransplant malignancy secondary to immunosuppression is a common event, being the second leading cause of death for such patients. Non-melanocytic skin cancer is the most common malignancy after renal transplantation. Malignancy risk reduction among transplant patients is a must even if malignancy is not associated with worse graft outcome. Specific cancer prevention, screening and treatment programs for those people are highly recommended.

\section{Conflict of interest}

None declared.

\section{References}

1. Choi SJ, Choi D, Kwon OJ. Incidence of post-transplant malignancy after renal transplantation: single center analysis. J Korean Soc Transpl [Internet]. The Korean Society for Transplantation; 2014;28(4):204-210.

2. Kluijfhout WP, Drake FT, Pasternak JD, Beninato T, Mitmaker EJ, Gosnell JE, et al. De novo thyroid cancer following solid organ transplantation - A 25-year experience at a high-volume institution with a review of the literature. J Surg Oncol. 2017 Feb 1;115(2):105-108.

3. Wahab KA, Attia E, Arafa M, Sorogy M El, Wahab MA. Micro-invasive papillary thyroid lesion in a post living donor liver transplant patient: A case report. Int J Case Reports Images. 2016;7(5):323-326.

4. Zhang J, Ma L, Xie Z, Guo Y, Sun W, Zhang L, et al. Epidemiology of post-transplant malignancy in Chinese renal transplant recipients: a single-center experience and literature review. Med Oncol. 2014;31(7):32.

5. Engberg H, Wehberg S, Bistrup C, Heaf J, Sørensen SS, Thiesson HC, et al. Cancer risk and mortality after kidney transplantation: a population-based study on differences between Danish centres using standard immunosuppression with and without glucocorticoids. Nephrol Dial Transplant. 2016;31(12):2149-2156.

6. Asch WS, Perazella MA. Cancer and mortality in solid-organ transplantation: preventable or inevitable? Am J Kidney Dis. Elsevier; 2018;68(6):839-842.

7. Wong G, Au E, Badve S V, Lim WH. Breast Cancer and Transplantation. Am J Transplant. 2017;17(9):2243-2253.

8. Tanaka T, Voigt MD. Decision tree analysis to stratify risk of de novo non-melanoma skin cancer following liver transplantation. J Cancer Res Clin Oncol. 2018;144(3):607-615.

9. Pendón-Ruiz de Mier V, Navarro Cabello MD, Martínez Vaquera S, Lopez-Andreu M, Aguera Morales ML, Rodriguez-Benot A, et al. Incidence and long-term prognosis of cancer after kidney transplantation. Transplant Proc. Elsevier; 2018;47(9):2618-2621.

10. Lee J, Jeong JJ, Lee YS, Nam KH, Chang HS, Chung WY, et al. Incidence and Clinical behavior of papillary thyroid 
carcinoma in renal allograft recipients: A single center experience. Transplant Proc. Elsevier; 2008;40(10):3751-3754.

11. Amre R, Michel RP. Transplantation and Malignancy BT - Pathology of Transplantation: A Practical Diagnostic Approach. In: Michel RP, Berry GJ, editors. Cham: Springer International Publishing; 2016. p. 451-476.

12. Gao PJ, Gao J, Li Z, Hu ZP, Zhu JY. De novo malignancy after liver transplantation: a single-center experience of 14 cases. Ann Surg Treat Res. 2015;88(4):222-228.

13. Sa A, Ka F, Daly C, et. al. Cancer mortality among recipients of solid-organ transplantation in ontario, canada. JAMA Oncol. 2016;2(4):463-469.

14. Miyazaki T, Sato S, Kondo T, Kusaka M, Gotoh M, Saiki $\mathrm{Y}$, et al. National survey of de novo malignancy after solid organ transplantation in Japan. Surg Today. 2018; Available from: https://doi.org/10.1007/s00595-018-1628-9
15. Acuna SA, Huang JW, Dossa F, Shah PS, Kim SJ, Baxter NN. Cancer recurrence after solid organ transplantation: A systematic review and meta-analysis. Transplant Rev. 2017;31(4):240-248.

16. Rama I, Grinyó JM. Malignancy after renal transplantation: the role of immunosuppression. Nat Rev Nephrol 2010;6:511.

17. Manuelli M, De Luca L, Iaria G, Tatangelo P, Sforza D, Perrone L, et al. Conversion to rapamycin immunosuppression for malignancy after kidney transplantation. Transplant Proc. 2010;42(4):1314-1316.

\title{
Синхронное развитие плоскоклеточного рака кожи и папиллярного рака щитовидной железы после транс- плантации почки: описание клинического случая
}

\author{
Омар Хамди ${ }^{1}$, Сара Раафат ${ }^{2}$, Амр Абузид ${ }^{1}$, Махмуд М. Салех ${ }^{1}$, Абдальхади М. Шебль ${ }^{2}$ \\ ${ }^{1}$ Отделение хирургической онкологии, онкологический центр университета Мансура \\ ${ }^{2}$ Отделение патологической анатомии, Факультет медицины, университет Мансура, Египет
}

\section{Резюме}

Вторичные злокачественные новообразования после трансплантации почек являются нередкими событиями. В этом сообщении мы рассматриваем одну из причин посттрансплантационной смертности. Сообщается о клиническом случае трансплантации почек с последующей иммуносупрессивной терапией и развитием через 11 лет синхронного плоскоклеточного рака кожи и папиллярной карциномы щитовидной железы, которые диагностировали и лечили в онкологическом центре университета Мансура.

\section{Ключевые слова}

Трансплантация почек, иммуносупрессивные препараты, синхронные злокачественные опухоли. 